\title{
Sobre a clonagem de embrióes: código de ética e código penal
}

LUIZ HILDEBRANDO PEREIRA DA SILVA

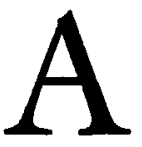

pesquisa biológica tem-se revelado para a sociedade, nos últimos tempos, uma fonte de preocupaçóes e de angústias. Foi-se

o tempo em que se identificava a imagem do pesquisador com a do velho bonachão de longas barbas brancas, olhar doce e gesto tranqüilizador. Hoje, na imagem popular, o pesquisador biomédico identifica-se mais com a figura de um jovem agitado, descabelado e um pouco desequilibrado, a refletir sobre diabruras e feitiçarias, transformando sapos em lagartos, criando dinossauros a partir de mosquitos fósseis, construindo quimeras animais.

Foi assim que não nos causou surpresa o impacto mediático dos trabalhos dà equipe do Dr. Stillman, da Universidade George Washington, nos EUA, publicado recentemente na revista Science (1). A experiência consistiu na multiplicaçáo in vitro de célula embrionária humana, dando origem a uma série de cópias capazes, em princípio, de originar organismos humanos idênticos. Esse tipo de manipulaçáo - comumente chamado de clonagem celular - é realizado de maneira rotineira em roedores, bovídeos e outros animais e não apresenta em si qualquer originalidade biológica em termos científicos. Entretanto, pelo fato de ser realizada com material de origem humana, gerou reaçôes hostis as mais diversas: o presidente francês Mitterand, republicano e laico, qualificou a experiência de "procedimento insuportável"; o Observatore Romano registrou a condenação sem apelo de Sua Santidade; o Parlamento europeu propôs a interdiçáo de experiências com embrióes humanos. Vozes unânimes se elevaram nas diferentes áreas da Sociedade Civil para exprimir inquietude e exigir a regulamentaçáo ética da experimentaçáo utilizando embriōes, tecidos e órgáos humanos. A opiniáo pública interroga os cientistas na busca de explicaçóes, de orientaçáo ou, ao menos, de informação.

Cremó, assim, ser útil abordar certos problemas invocados em torno das experiências de Stillman. Os progressos das ciências básicas e de suas aplicaçóes médicas colocam, șem dúvida, problemas éticos no- 
vos. É necessário abordá-los e procurar definir códigos que compatibilizem os novos recursos de intervençáo com a tradição e o progresso cultural das sociedades, dentro do respeito à individualidade e à dignidade da pessoa humana. Entretanto, é talvez mais urgente desdramatizar certos aspectos de problemas que despertam fantasmas do inconsciente e são levantados por razóes demagógicas, falsamente científicas, desvirtuando o debate.

Tratemos, pois, de dois aspectos profundamente explorados pela mídia em torno das experiências de clonagem e que provocaram profundo mal-estar na opiniấo pública.

O primeiro, coloca a problemática do admirápel mundo nopo, de Huxley, com o pânico que desperta a idéia de alguém poder, com objetivos eventualmente maléficos, fabricar centenas ou milhares de indivíduos humanos idênticos. Esse aspecto teria sido provavelmente ignorado, no que se refere às experiências de Stillman, se o autor, ele mesmo, para se defender dos ataques do Observatore Romano não assumisse posição de indignação ética ao proclamar que o "direito à procriaçáo é um dos direitos fundamentais do gênero humano" (2). Parece portanto que, para Stillman, as experiências de clonagem de embriáo teriam um valor positivo para abrir possibilidades novas de procriação. Teriam mesmo?

Pretender que os embriōes clonados ofereçam maiores possibilidades de sucesso ou garantias particulares sobre a qualidade do produto de concepçáo é atitude arriscada. Pode-se criar o mesmo tipo de ilusáo, que beira à vigarice, desenvolvida por certa empresa americana que gerou um banco de esperma de premios Nobel. Na verdade, todos sabem que um prêmio Nobel, como qualquer outro ser humano fértil do sexo masculino, produz espermatozóides de grande diversidade. A chance para que um espermatozóide de suas entranhas reúna combinação de genes correspondente a que o conduziu à glória efêmera é equivalente à chance que um outro exemplar reúna combinação dando origem a um débil mental. Quando o público foi esclarecido sobre esse ponto, o esperma de prêmios Nobel saiu da moda. Será que agora querem vender embrióes pré-fabricados? E em série?

Um embrião, verdade seja dita, é geneticamente constituído e tem um potencial determinado. Mas nem por isso ele é mais seguro de conter um bom potencial. Simplesmente porque um potencial genético não pode ser avaliado senáo por sua realização, isto é, deixando-o exprimir-se em meio definido. Ora, isso quer dizer, em termos de embriōes humanos, que se deve esperar que ele nasça e viva para se saber o que 
vale. Dever-se-á, portanto, nas putativas clínicas especializadas de embriōes clonados, oferecer aos clientes cópias de embriôes já submetidos aos ensaios.

O que é um ensaio para um embriāo humano? É simples. É uma experiência de vida. É o resultado de suas realizaçōes no decurso da existência, ou seja, para um embrião de origem brasileira, segundo as expectativas de vida ao nascer, uma média de 65 a 70 anos de observação. Mas, além disso, deve-se considerar que as realizaçóes da vida, a partir do potencial genético, dependem de uma série enorme de fatores aleatórios que começam cedo para um embriáo: de início, as incompatibilidades materno-fetais conhecidas e desconhecidas no plano neuroendocrinológico, imunológico e outros; em seguida, a aventura de se adaptar à bacia pélvica da mãe de adoção, que irá estabelecer as condições do parto e suas repercussóes futuras.

A seguir, depois do nascimento, o embriáo que virou Homem deverá enfrentar as enormes variaçóes de meio - físico e social -, de educação, de higiene, de normas impostas ou adotadas etc. Isto implicaria, segundo critérios científicos, que as eventuais clínicas produtoras de embriōes clonados, antes de poder oferecer cópias às clientes, lançassem de início uma série de exemplares em ensaio, tendo em conta o número de variáveis implicadas, para que a experiência tivesse significação estatística. Deve-se, portanto, admitir que a clínica encontraria o número necessário de mães de ensaio. Em seguida, que ela organizasse o exército de especialistas que deveriam observar discretamente a experiência de vida de cada embriáo experimental, desde a implantaçáo uterina até o nascimento e, depois, até a morte. A clínica poderia então, em meados do século XXI, oferecer às clientes candidatas um quadro de probabilidades de performances dos exemplares congelados de embrióes clonados em seu poder. Mas, como daqui até lá as condiçóes de meio físico e social teriam mudado profundamente, a experiência teria pouco ou nenhum valor.

O grande geneticista Benno Müller Hill, professor da Universidade de Colônia, exprimia recentemente, na revista Nature (3), sua inquietação a respeito da evolução das pesquisas sobre o genoma humano e o receio de que as pesquisas anônimas sobre fatores genéticos da inteligência e/ou da predisposiçāo para as doenças mentais pudessem conduzir à formulaçấo de bases genéticas para justificar as injustiças sociais ou o racismo. A experiência histórica revela, com efeito, que sempre se encontra alguém capaz de fazer qualquer coisa, por pior que seja. Como os geneticistas náo escapam à regra, é possível que se encontre entre eles os que aceitariam desenvolver a clonagem de embrióes 
humanos e, mesmo alguns, que iriam fazer a publicidade de seus clones com experiências cientificamente significantes realizadas há cinco ou dez anos. Como os wiskies e os conhaques. Mas é também evidente que tais procedimentos poderão ser facilmente enquadrados no Código Civil, sem necessidade de qualquer novo código de ética.

Examinemos agora o segundo aspecto, que impressionou muito a opiniáo pública, com relaçáo às experiências de clonagem. Trata-se do que se pode chamar de complexo do sósia. Insinuou-se, em certos comentários da imprensa, que um embriâo congelado, de quem seríamos irmão(ã) gêmeo(a), nos seria de grande utilidade, no momento de um transplante de órgão, à vista da compatibilidade absoluta de nossas células e de nossas secreçôes. Teríamos, assim, à disposição, em reserva, verdadeiros retratos à maneira de Dorian Gray, a quem transferir nossos males e defeitos, conservando a juventude eterna. A temática, plágio à parte, prestou-se a muitas obras de ficçáo científica de valor duvidoso. Pode isso ser levado a sério?

Desenvolvem-se atualmente pesquisas sobre culturas de células e tecidos embrionários ou fetais a serem utilizados eventualmente em transplantes terapêuticos para doenças hipofisárias, do sistema hematopoiético, entre outras. Essas pesquisas envolvem procedimentos cuja regulamentação ética não foi até agora bem-definida. Certamente é necessário fazề-lo. A regulamentação ética da intervenção médica na procriação deve também desenvolver-se em face dos progressos técnicos atuais. Tudo isso nada tem a haver com o sósia congelado.

Com efeito, um embriáo congelado nosso irmáo, não seria de qualquer utilidade. Para que ele fosse útil, seria necessário deixá-lo nascer ao mesmo tempo que nós mesmos, ou ao menos em épocas aproximadas. Ora, tal decisão não pode ser tomada por um recém-nascido, mas apenas pelos pais adotivos que deverão providenciar a procriaçăo de um irmão ou irmã gêmea em mãe portadora benévola ou remunerada. Além disso, se tal procedimento fosse observado, de nada valeria sem que a informação chegasse ao nosso conhecimento na idade de razáo. Ficaríamos, assim, informados da existência de um sósia, em caso de necessidade. Esse cenário coloca, entretanto, problemas incontornáveis: Por exemplo, seria necessário assegurar-se da cumplicidade do sósia, difícil de imaginar, ou mantê-lo na ignorância, mas ocupar-se de seu bem-estar e de sua higidez. Difícil! Sem falar nas indiscriçóes eventuais que nos deixariam em situação inconfortável de ter de agir como o cosp-boy Lucky Luke - o que atirá mais rápido que a sombra.

De tudo o que acabamos de dizer pode-se pensar que sejamos 
indiferentes às experiências da equipe Stillman. Muito pelo contrário. Se fôssemos membros da comissão científica do órgão financiador da experiência (que deve ter custado caro) teríamos emitido o julgamento seguinte:

"Os autores pretendem mostrar que é possível obter clones de células embrionárias toti-potentes, a partir de embrióes humanos. $\mathrm{O}$ fenômeno é observado em condiçóes naturais, no caso de gêmeos univitelinos e náo há, portanto, a esperar resultados científicos originais. Quanto ao aspecto técnico, a clonagem experimental foi abundantemente demonstrada e é de utilizaçáo corrente em roedores, ruminantes e outros mamíferos. A proposição de clonagem de embriāo humano não teria assim outro objetivo senão o de demonstrar ainda uma vez que o homem é um mamífero, fato conhecido mesmo antes de Darwin. Quanto ao interesse prático da operação ele pode ser considerato nulo. Financiamento recusado."

Notas

1 J.L.Hall et al. Experimental cloning of human polyploid embryos using an artificial zona pelucida. Science, v. 262 (em publicaçāo).

2 Extratos de entrevistas coletiva à imprensa dos Drs. Hall e Stillman. New rork Times, 25 out. 1993.

3 B. Müller Hill. Nature, v.362, 1993, p.491.

Luiz Hildebrando Percira da Silva é professor aposentado da Universidade de São Paulo (Departamento de Parasitologia, da Faculdade de Medicina da USP em São Paulo) e atualmente é professor do Instituto Pasteur, de Paris. 